\title{
First record of Pulvinaria regalis CANARD, 1968 (Hemiptera: Coccomorpha: Coccidae) in Poland
}

\author{
Bożena ŁagOWSKA ${ }^{1}$, KATARZYNA GOLAN $^{1 *}$, MAREK MichalsKi $^{2}$ \\ ${ }^{1}$ Department of Plant Protection, University of Life Sciences in Lublin, Leszczyńskiego 7, \\ 20-069 Lublin, Poland \\ ${ }^{2}$ Department of Experimental Zoology and Evolutionary Biology, University of Łódź, \\ Banacha 12/16, 90-237 Łódź, Poland
}

\begin{abstract}
Pulvinaria regalis has been recorded for the first time in Poland. This species was observed in large numbers on Acer pseudoplatanu, A. platanoides, Aesculus hippocastanum, Robinia pseudacacia, Tilia $\times$ euchlora and T. cordata in urban areas. Basic diagnostic information for this species and a key to separate the species of Pulvinaria recorded in Poland is provided. Aspects of the distribution, biology and economic importance of $P$. regalis are also discussed.
\end{abstract}

KEY WORDS: Horse chestnut scale, alien pest, diagnosis, key.

\section{INTRODUCTION}

The scale insect of the genus Pulvinaria TARgIONI-TozzetTI, 1866 (Hemiptera: Coccomorpha: Coccidae) comprises 142 species of which 67 are known from the Palaearctic region. In Europe, 15 species of Pulvinaria have been recorded outdoors, namely: P. ampelopsidis SAVESCU, 1983, P. brachiungualis SAVESCU, 1985, P. corni Savescu, 1986, $P$. elongata Newstead, 1917, P. fraxini Signoret, 1873, $P$. floccifera (Westwood, 1870), $P$. hydrangeae SteInWEden, 1946, P. regalis CANARD, 1968, $P$. salicis (Bouché, 1851), P. savescui BEN-Dov, 1993, P. sericea (FourCROY, 1785), P. simplex KING in HoFer, 1903, P. tremulae SigNORET, 1873, P. vinifera KING in HoFer,

\footnotetext{
*Corresponding author: katarzyna.golan@up.lublin.pl
} 
1903, and P. vitis (LinNaeus, 1758) (GARCÍA Morales et al. 2016). In this group of species, $P$. vitis, $P$. floccifera, $P$. hydrangeae, $P$. regalis are well-known soft-scale insects, widely distributed in Europe. Almost all of them ( $P$. floccifera, $P$. regalis and $P$. hydrangeae) are considered economic, alien pests in many European countries (PELLIZZARI \& GERMAIN 2010). Several other Pulvinaria species reported from Europe have not been recorded any more, since their descriptions and identities are uncertain. According to Hodgson (1994), the genus Pulvinaria is in great need of revision.

Adult females of Pulvinaria are typically characterized by the production of woolly ovisacs that protrude from beneath the posterior end of the abdomen, and also by the presence of (i) small dorsal tubular ducts; (ii) tibio-tarsal articulatory sclerosis; and (iii) ventral tubular ducts of three or four types, including (a) a short duct with an inner ductule without glandular ends, typically present in a broad submarginal band extending from the anal cleft to near the antennae, (b) a large duct with an inner ductule of similar length and width, and a large terminal gland, usually present in the median areas of the head, thorax and the more anterior abdominal segments, and (c) intermediate ducts with a narrow inner ductule and a large terminal gland, usually frequent medially on the more posterior abdominal segments (HODGSON 1994).

To date, only two species of Pulvinaria have been identified in Poland: $P$. vitis and $P$. floccifera. The former is considered to be native to Poland, whereas the latter is classified as an alien invasive scale insect. In Poland, both species are restricted to wild and cultivated woody plants (ŁAGOWSKA 1996, ŁAGOWSKA et al. 2015, 2017).

The present study reports the first record of $P$. regalis in Poland, provides some basic diagnostic information for this species and provides a key for identifying all Pulvinaria species recorded in Poland.

\section{MATERIAL AND METHODS}

Scale insects were collected from roadside lime trees in the city of Łódź (Mazovian Lowland). Samples of bark, twigs and leaves were taken to the diagnostic laboratory of the Department of Plant Protection, University of Life Sciences, Lublin, for slide-mounting and identification. Specimens (adult females and first-instar nymphs) were mounted in Canada balsam, in accordance with the method of HODGSON \& HENDERSON (2000), and were identified by the first author based on adult female morphology and first-instar larvae, as described by CANARD (1968). The morphological features of adult females were consistent with those defined by HodGSON (1994). The key was constructed on the basis of morphological data given in CANARD (1968), HODGSON (1994), LAGOWSKA (1996) and HODGSON \& HENDERSON (2000). In addition, specimens of $P$. regalis from Sweden were 
used for comparative purposes during this study. Both the dry and mounted specimens were deposited at the Department of Plant Protection, University of Life Sciences, Lublin.

\section{RESULTS}

All the specimens of Pulvinaria collected in Łódź were identified as Pulvinaria regalis: this is the first record of this species in Poland. Adult females with ovisacs (Fig. 1a, b) were observed on the trunks and main branches of Acer negundo L., A. pseudoplatanus L., A. platanoides L., A. rubrum L., Aesculus hippocastanum L., Robinia pseudacacia L., Tilia $\times$ euchlora $\mathrm{K}$. KосH, T. cordata MiLL. and Ulmus sp., while first-instar nymphs were found on the leaves of the host plants. Lime, maple and chestnut trees growing along roadsides and in housing estates were the most seriously infested by $P$. regalis.

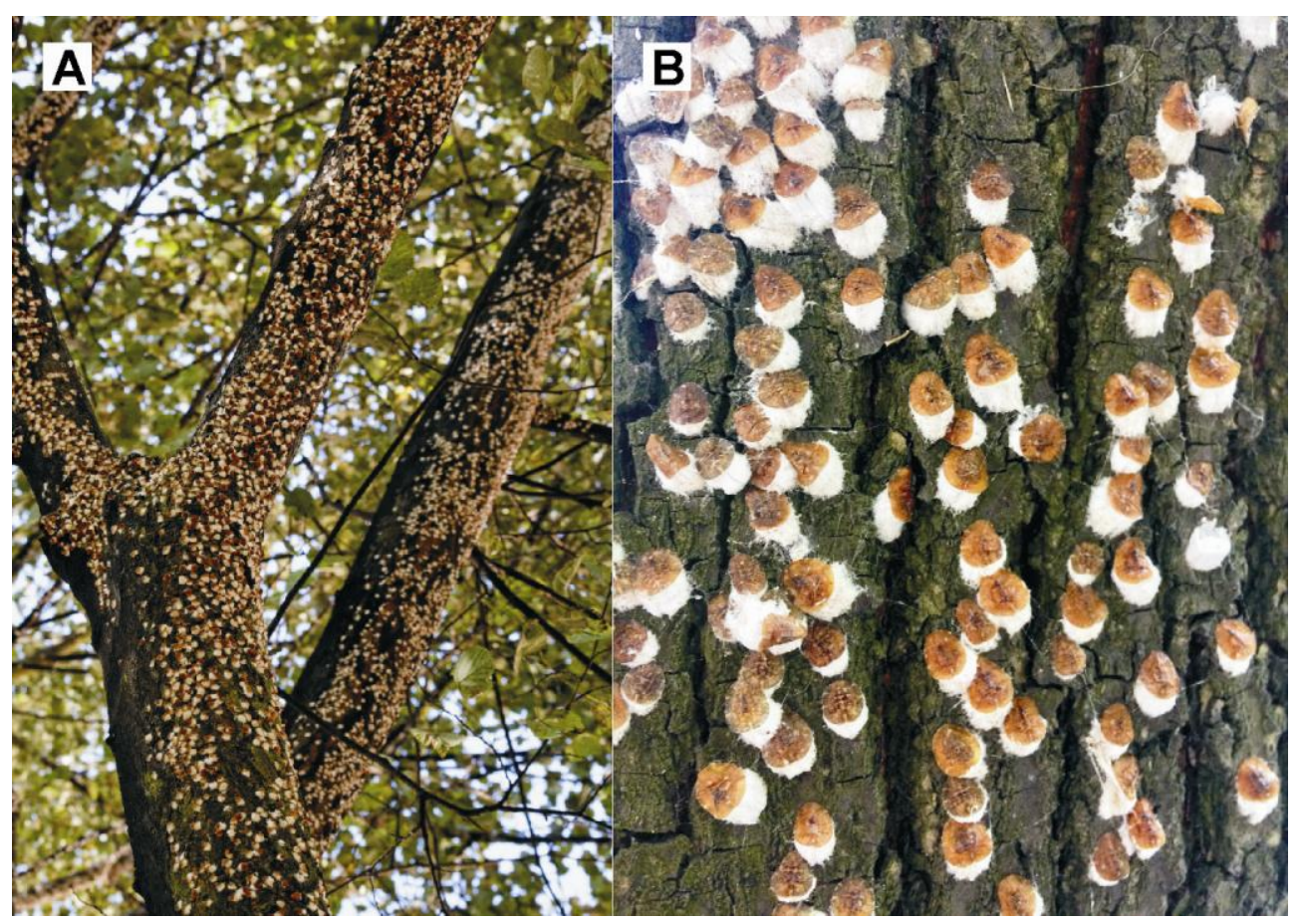

Fig. 1. Pulvinaria regalis CANARD 1968, old adult females with ovisacs on the trunk of a lime tree. A - general view, B - close up view (Photo M. MiCHALSKI). 


\section{Material examined}

Poland: Łódź, $51^{\circ} 45^{\prime} 00^{\prime \prime} \mathrm{N}, 1^{\circ} 28^{\prime} 00^{\prime \prime} \mathrm{E}, 192 \mathrm{~m}$; 8.vii.2018, coll. M. MichalSKI; on stems and leaves of Tilia $\times$ euchlora $\mathrm{K}$. KoCH; 6 slides with 6 adult females and 4 slides with 13 first-instar nymphs; 3 envelopes with dry material; Sweden: Malmö, 55³6'21"N, $13^{\circ} 00^{\prime} 09^{\prime \prime}$, det. C-A. GERTSSON, 2 slides with 2 adult females collected on Tilia sp.

\section{Diagnosis}

Unmounted specimens. Young adult female almost circular, pale grey-brown in colour with yellow spots at the level of the eyes, stigmatic furrows and body axis to anal plaques. Dorsum marked with a longitudinal ridge and two transverse ridges pointing towards the stigmatic furrows (Fig. 2). When oviposition starts, the females secrete a waxy white ovisac, which is almost as long as the body when complete. At the end of egg laying, the adult female is tobacco brown in colour and remains flat. It is 5.3-6.9 mm long and 4.3-6.5 mm wide.

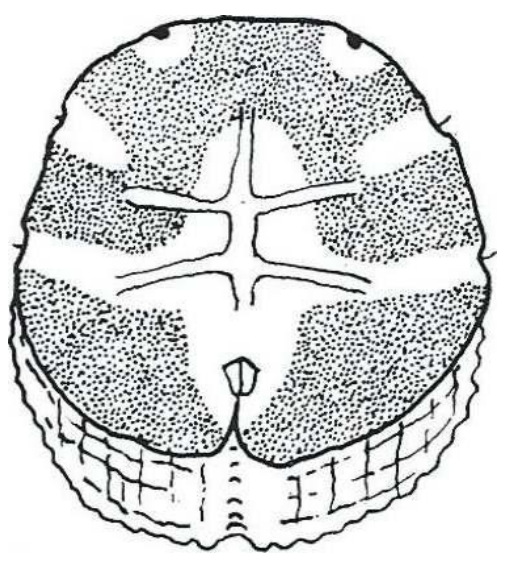

Fig. 2. Pulvinaria regalis CANARD 1968, young adult female (dorsal view) with ovisac (Adopted from CANARD 1968).

Mounted specimens. Body almost circular, sometimes wider than long. Antennae well developed, each with 8 segments. Legs exceptionally large, each with a tibio-tarsal articulatory sclerosis, claw without a denticle. Stigmatic clefts, each with 3 stigmatic spines; median spine about $104 \mu \mathrm{m}$ long, bluntly pointed; lateral spines, each about $40 \mu \mathrm{m}$ long. Marginal setae numerous, slender and pointed, straight or slightly curved, each seta about $40 \mu \mathrm{m}$ long (CANARD 1968). Anal plates together quadrate, each plate with 1 apical and 2 subapical setae. Preopercular pores, each 2-5 $\mu \mathrm{m}$ wide, present in a group of 80-100 pores anterior to anal plates. Tubular ducts of various types and sizes, present on venter. Spiracular disc-pores, each 5-7 $\mu \mathrm{m}$ wide with 5 loculi, present in bands, 1-2 pores wide, 
with 90-165 pores per band (CANARD 1968). Multilocular disc-pores, each 8-11 loculi, scattered over the anterior part of the abdomen, around the posterior spiracles, sometimes even further. Numerous microducts and setae present on the venter and dorsum. Dorsal tubular ducts and submarginal tubercles absent.

Key to Pulvinaria species recorded in Poland, based on adult female morphology

1. Dorsal tubular ducts and submarginal tubercles absent. P. regalis CANARD, 1968

- Dorsal tubular ducts and submarginal tubercles present. 2

2. Marginal setae spinose, frayed, bifid or finely pointed, multilocular disc-pores usually with 7 loculi; claw without denticle. P. floccifera (WESTWOOD, 1870)

- Marginal setae all spinose, finely pointed, never frayed or divided; multilocular discpores with mainly 10 loculi, claw with a small denticle. P. vitis (LinNAEUS, 1758)

\section{DISCUSSION}

Pulvinaria regalis was originally described from specimens collected on Tilia vulgaris Hayne in Paris (CANARD 1968). Since then, this species has spread right across Europe. To date, it has been recorded in the United Kingdom (HARRIS 1970, MALUMPHY \& BADMIN 2012), Belgium (MERLin \& PASTEels 1990), the Netherlands (JANSEN 1996), Germany (SENGONCA \& FABER 1995, SCHRODER \& Richter 2003), Switzerland (KozÁR et al. 1994), Denmark (GERTSSON 2007), Sweden (GERTSSON 2011), Ireland (O`CONNOR et al. 2013) and recently in Poland.

In total, three Pulvinaria species have been reported in Poland, but $P$. regalis may be confused with $P$. vitis if solely field characters are employed for identification. Young adult females of both species produce waxy white ovisacs and they dry up and remain flat, attached at the anterior end of the ovisacs after the eggs have been laid (dry adult females usually falls off in $P$. floccifera). In addition, both $P$. regalis and $P$. vitis are polyphagous and can attack the same species of host plants.

Here, we provide a key (see above) for distinguishing $P$. regalis from its relatives recorded in Poland. Microscopically, P. regalis differs from the two other Pulvinaria species identified in Poland mainly in the lack of tubular ducts and submarginal tubercles on the dorsum. Tubular ducts are present only on the venter of $P$. regalis - they produce long white filaments, which are associated with the construction of the ovisac (FOLDI \& PEARCE 1985).

P. regalis is a highly polyphagous species, its host spectrum covers trees and shrubs of 24 families and 29 genera. Aesculus, Acer and Tilia are among the most seriously infested 
genera, followed by Magnolia and Cornus (SCHMITZ 1997). It develops one generation per year, and the third-instar nymphs overwinter (HIPPE \& FREY 1999). Development to adults is completed during spring on the woody parts of plants, where adult females form ovisacs and lay eggs in late April to May. Crawlers hatch from the end of May and move to the leaves of their host plants where they settle and feed until September or October. Prior to the autumn leaf fall, the third-instar nymphs move to the branches and trunk to overwinter (HIPPE \& FREY 1999).

$P$. regalis has been reported as serious, invasive pest of ornamental plants in urban areas (mainly roadside pavements, paved squares, car parks, parks) in Switzerland, Germany and other European countries (SENGONCA \& FABER 1995, HIPPE \& FREY 1999, KÖHLER \& NUSSBAUM 2009). In Poland, serious infestations were observed mainly along roadsides and estate trees in 2018. This univoltine species has an enormous reproductive capacity; each adult female lays 2500-3000 eggs (CANARD 1968) and the first-instar nymphs spread with the wind to new host trees.

Nevertheless, the impact of $P$. regalis is mostly regarded as an aesthetic problem that is caused by adult females with their waxy white ovisacs in late spring. Some authors claim that $P$. regalis has little effect on the health of colonized trees, so control measures are not necessary except in the case of high-quality trees (SCHRÖDER \& RICHTER 2003, TRIERWEILER \& BALDER 2005).

\section{ACKNOWLEDGEMENTS}

The authors are very grateful to MSc Barbara LOGA (Natural History Museum, University of Łódź) for valuable information about Pulvinaria specimens, and to Carl-Axel GERTSSON for the loan of slides with $P$. regalis adult females from his collection.

\section{REFERENCES}

CANARD M. 1968. Un nouveau Pulvinaria (Hom. Coccoidea) nuisible aux arbres d'alignement dans la région Parisienne. Annales de la Société Entomologique de France (N.S.), 4: 951-958.

FOLDI I., PEARCE M.J. 1985. Fine structure of wax glands, wax morphology and function in the female scale insect, Pulvinaria regalis CANARD. (Hemiptera: Coccidae). International Journal of Insect Morphology and Embryology, 14 (5): 259-271.

García Morales M., Denno B., Miller D.R., Miller G.L., Ben-Dov Y., Hardy N.B. 2016. ScaleNet: A literature-based model of scale insect biology and systematics. Internet: http://scalenet.info (accessed 10 September 2018) 
Gertsson C.A. 2007. Pulvinaria regalis CANARD - a new Danish scale insect (Hemiptera: Coccoidea). Entomologiske Meddelelser, 75 (2): 147-149. (in Swedish)

GERTSSON C.A. 2011. New species and new province-records of scale insects from Sweden (Hemiptera: Coccoidea) up to the year 2010. Entomologisk Tidskrift, 132 (1): 39-45. (in Swedish)

HARRIS K.M. 1970. Horse chestnut scale. Arboricultural Association Journal, 1: 257-262.

HiPPE C., FREY J.E. 1999. Biology of the horse chestnut scale, Pulvinaria regalis CANARD (Hemiptera: Coccoidea: Coccidae) in Switzerland. Entomologica, 33: 305-309.

Hodgson C.J. 1994. The scale insect family Coccidae: an identification manual to genera. CAB International, Wallingford, Oxon, UK.

Hodgson C.J., Henderson R. 2000. Coccidae (Insecta: Hemiptera: Coccoidea). Fauna of New Zealand, 41: 1-264.

Jansen M.G.M. 1996. The genus Pulvinaria in the Netherlands (Coccinea: Coccidae). Aphids and Other Homopterous Insects, 5: 59-63.

KÖHLER G., Nussbaum R.P. 2009. Invasive Schildlausarten auch in Thüringen: Pulvinaria regalis CANARD, 1968 und Diaspidiotus perniciosus (COMSTOCK, 1881) (Insecta: Coccina: Coccidae, Diaspididae). Thüringer Faunistische Abhandlungen, 14: 113-124.

Kozár F., Guignard E., Bachmann F., Mani E., Hippe C. 1994. The scale insect and whitefly species of Switzerland (Homoptera: Coccoidea and Aleyrodoidea). Mitteilungen der Schweizerischen Entomologischen Gesellschaft, 67(1-2): 151-161.

Łagowska B. 1996. Pulvinaria TARgioni-Tozzetti (Homoptera, Coccidae) in Poland. Wydawnictwo Akademii Rolniczej w Lublinie, Lublin.

Łagowska B., Golan K., Kot I., Kmieć K., Górska-Drabik E., GoliszeK K. 2015. Alien and invasive scale insect species in Poland and their threat to native plants. Bulletin of Insectology, $\mathbf{6 8}$ (1): 13-22.

Łagowska B., Golan K., KMieć K., Kot I., Górska-Drabik E., Goliszek K. 2017. The phenology of Pulvinaria floccifera WESTWOOD (Hemiptera: Coccomorpha: Coccidae), a new invasive pest on ornamentals outdoors in Poland. Turkish Journal of Zoology, 41 (1): 113-118.

MALUMPhy C.P., BADMIN J.S. 2012. Scale Insects and Whiteflies (Hemiptera: Coccoidea and Aleyrodoidea) of Watsonian Kent; with a Discussion on the Impact of Naturalised Non-native species. British Journal of Entomology and Natural History, 25: 15-49.

MeRlin J., PASTEEls J.M. 1990. Sprouting of genus Pulvinaria in urban areas; current situation and its control. Actes du colloque Gérer la Nature. Travaux Conservation de la Nature, 15: 607-618.

O`CONNOR J.P., GeRTSSON C.A., MALumPhy C. 2013. A review of the Irish scale insects (Hemiptera: Coccoidea). The Irish Naturalists`Journal, 32 (1): 32-44.

PellizZari G., Germain J.F. 2010. Scales (Hemiptera, Superfamily Coccoidea). [in:] A. RoQues, M. Kenis, D. Leeds, C. Lopez-VAamonde, W. Rabitsch, J.-Y. Rasplus, D.B. RoY (reds.). Alien terrestrial arthropods of Europe. BioRisks 4 (1): 475-510.

SCHMitz G. 1997. To the host plant spectrum of Pulvinaria regalis CANARD (Hom., Coccidae). Gesunde Pflanzen, 49: (2) 43-46. 
SChröder T., Richter E. 2003. Die Wollige Napfschildlaus Pulvinaria regalis CANARD, 1968 (Homoptera, Coccidae) - ein neuer Schädling an Braunschweigs Stadtbäumen. Braunschweiger Naturkundliche Schriften, 6 (4): 803-812.

Sengonca C., Faber T. 1995. Beobachtungen über die neu eingeschleppte Schildlausart Pulvinaria regalis CANARD an Park- und Alleebäumen in einigen Stadtgebieten im nördlichen Rheinland. Zeitschrift für Pflanzenkrankheiten und Pflanzenschutz, 102 (2): 121-127.

TRIERWEILER P., BALDER H. 2005. Spread of horse chestnut scale (Pulvinaria regalis) in Germany. [in:] Plant Protection and Plant Health in Europe: Introduction and Spread of Invasive Species, Humboldt University, Berlin, Germany, 9-11 June 2005. BCPC Symposium Proceedings, no. 81. British Crop Production Council, Alton, 285-286.

Received: 1 October 2018

Accepted: 3 December 2018 